\title{
Industrial (Brewery) and Municipal Wastewater Production and Treatment: A Review Paper
}

\author{
Zulu Bernard ${ }^{1}$, Flory Kilingo ${ }^{2}$ and Prof. Chen Hongbin ${ }^{3}$
}

\begin{abstract}
${ }^{1}$ UNEP-TONGJI Institute of Environmental Sciences and Sustainable Development (IESD) Tongji University, Shanghai, China. 200092.
${ }^{2}$ UNEP-TONGJI Institute of Environmental Sciences and Sustainable Development (IESD) Tongji University, Shanghai, China. 200092.

${ }^{3}$ Correspondence: The State Key Laboratory of Pollution Control and Resource Reuse, School of Environmental Sciences and Engineering, Tongji University, Shanghai, China. 200092
\end{abstract}

DOI: 10.29322/IJSRP.11.06.2021.p11411

http://dx.doi.org/10.29322/IJSRP.11.06.2021.p11411

\begin{abstract}
Freshwater shortage and pollution-induced by human activities have become a global concern. Water resources pollution particularly by the brewing industries is a major concern due to production of large volume of wastewater resulting from large volume of water used in the production processes of beer. African countries consume much volume of water higher than the accepted international benchmark of 6.5 hectoliter water/hectoliter beer production. Observed about $60 \%$ of freshwater used in Zambian breweries in the brewing of beer and finishing operations. The industries are observed to generate large volume of wastewater and discharge it partially treated or untreated to the environment resulting to degradation of ecosystem and outbreak of cholera and typhoid. Zambia being a developing country is facing challenges in wastewater management. The treatment plants produce large volume of sludge and are overfilled due to poor maintenance and operation. The wastewater treatment facilities with conventional treatment systems are hydraulically overloaded with effluent quality of COD at an average of 817 $\mathrm{mg} / \mathrm{L}$, BOD $148 \mathrm{mg} / \mathrm{L}$, turbidity 58.4NTU which were observed to be above the allowable limits for Zambia Environmental Management Agency (ZEMA) at $90 \mathrm{mg} / \mathrm{L}, 50 \mathrm{mg} / \mathrm{L}$, and $15 \mathrm{NTU}$ respectively. The waste stabilization ponds (WSPs) effectively removed the BOD to an average of $32.5 \mathrm{mg} / \mathrm{L}$ within the set limits and a poor effluent quality of turbidity (86.3 NTU) and COD (143 $\mathrm{mg} / \mathrm{L}$ ) above the set limits. Therefore, further treatment of the effluent is to be proposed for the treatment of the high concentrated water effluent from the treatment plants. This review aims at stating the current situation of industrial (brewery industries) and domestic or municipal wastewater in Zambia, as well as its environmental impacts, methods for treatment and the solution to the provision of the required effluent quality for discharge to the environment without causing pollution to water sources and aquatic life.
\end{abstract}

Index Terms- Brewery wastewater, environmental pollution, industrial effluents, physicochemical composition

\section{INTRODUCTION}

$\mathrm{W}$ ater is a basic necessity in all the undertaking for mankind. The water utilization in volumes and method of use is different from one civilization to the other (Stéphanie, 2018). Worldwide the water is seen as a natural resource in a free flow either underground, or as surface water, its source or availability for use is not indefinite (Grogan et al., 2017). African countries face water shortage even though there are plentiful water resources of which differ broadly in terms of water distribution and availability for use. African countries mostly use the water from sources such as rivers, for irrigation in the agricultural sector, and for drinking, laundry, cooking, and others in households (Rijsberman, 2006). However, many concerns about water quality are widespread, but the true scope of the problem is uncertain. Moreover, domestic or industrial usage, a huge amount of the freshwater is turned into wastewater and is disposed into surface water and or groundwater in a treated or untreated form (Sayo, 2005). Additionally, water source pollution is a major challenge especially in third-world countries, with an estimation of about $90 \%$ of sewage and $70 \%$ of industrial wastewater is discharged into the environment without treatment (Cooley et al., 2014).

The wastewater causing water pollution, algal growth and risk to human wellbeing and other living organisms originates from different sources of production such as industries, household, municipal, hospital and also from the agricultural sector of which it may consist of several organic and inorganic elements, that can react to even form many more compounds at the discharged point. However, despite the source of generation of the wastewater, whether industrial or domestic, the raw wastewater contains nutrients in different concentrations (National Research Council, 2012) and its percentage composition of the contaminants in the treated or partially treated is complex and varies according to its usage. Therefore, effective methods for the determination of the level of wastewater contaminants concentration and mode of discharge are to be taken into consideration to prevent large release of the highly concentrated effluents to different environments posing risk to human health and aquatic life.

Wastewater literally and the true fact is that, its production from any source contains contaminants of high concentration which requires treatment before discharged to the environment. The industrial, municipal and domestic generated wastewater, particularly in developing countries such as Zambia are released to the environment without proper management. The open sewer lines and poorly operated septic tanks are mainly used as a way of the managing the household generated wastewater. The brewery industries are widespread in Africa and they require a large amount of freshwater for the generation of the product. The brewing sector is observed as a major part of the global economy, 
and its production processes is one of the sources that generate large quantities of wastewater (Fillaudeau et al., 2006, Simate et al., 2011, Enitan et al., 2015, Jaiyeola and Bwapwa 2016). Owing to rapid population growth, most African brewery industries', consumption of water is much higher than that accepted by the international benchmark practice of 6.5 hectoliters water per hectoliter beer (hl water/hl beer) production (UNEP 2017). However, for efficiently operated brewery industry can use about 4 liters or more for the generation of 1 liter of beer as opposed to inefficiently operated industries which can consume a double or even triple volume of water in the production. Moreover, according to (Simate et al., 2011), the production of one liter of beer can consume 3-10L effluent waste which is determined by the amount of water used in the processes. Brewery industries particularly in African countries such as Zambia, as estimated by (Ronald, 2011) about $60 \%$ of the clean water is used for brewing of beer and finishing operations.

Besides, in Zambia, currently there are five main breweries in the beer industry; Zambian, National, Capitol, Chat, and City breweries and are all based in cities, where they compete for water with domestic demand (Sutton and Langmead 2013). The breweries are categorized into two kinds; those producing the 'western' style lager beer and those producing the traditional 'chibuku' beer. Moreover, there are two major 'conventional' brewery factories and both use the 'package' western method. Additionally, Zambia has more than eighteen local breweries most of which produce traditional beer commonly known as 'chibuku' which is quite popular among the lower-income Zambians because it's relatively affordable. It's also anticipated that the consumption of 'conventional' beer is apt to continue rising and consequently the huge amount of wastewater generated will also increase (Haworth, 2004).

The production of the beer undergoes several processes involving biochemical, physical and chemical which are categorized as rough beer and wort clarification and separation in physical processes and boiling, fermentation and maturation, mashing as biochemical and chemical reaction processes. However, malt, milling, mash tuning, coppering, hop backing, wort cooling and aeration, fermentation, cellaring, and filtration are the most important processes in conventional brewing (Figure 1) and fermentation of sorghum grits, maize, malt and large volume of water are the basic raw materials used for 'traditional' breweries (Enitan et al., 2015). The filtration and the fermentation processes are observed to contain about 97\% BOD concentration at the effluent wastewater generated. The processes for the beer brewing involved consumption of large amount of freshwater, thus leading to generation of large volumes of polluted water to the environment (Figure 3) as stated by (Simate et al., 2011). Also, the study explained the large volume of wastewater generated from these industries are sometimes discharged to water bodies such as rivers, lakes and others leading to severe pollution problem in the water due to high organic contents such as COD and BOD that require oxygen for degradation, $\mathrm{pH}$ of a range $2-12$, high temperature ranging from $25^{\circ} \mathrm{C}-38^{\circ} \mathrm{C}$.

The traditional beer is prepared by cooling the maize, converted to a liquid form, and strained to create a yellowishbrown beer known as 'chibuku.' (Figure 2) (Nyuur and Sobiesuo 2016). The beer production processes by the conventional and traditional breweries in Zambia lead to the generation of a large volume of wastewater due to the consumption of a large volume of freshwater of about 4 to $8 \mathrm{~m}^{3} / \mathrm{m}^{3}$ of a produced beer as estimated from the literature (Kebede 2018) and an average consumption of $6 \mathrm{hl}$ of freshwater for the production of $1 \mathrm{hl}$ beer (Enitan et al. 2015). Furthermore, the generated wastewater from the brewery industries is discharged to water resources such as lakes, rivers, streams, and sewer lines at partially treated or even not treated due to inadequate and inefficient management systems leading to environmental pollution, and risk to human wellbeing and aquatic life due to a high concentration of pollutants such as biological and chemical oxygen demand, total suspended solids and also high nutrients loads. The country is also faced with a challenge of inadequate improved sanitation services and facilities that leads to outbreak of waterborne diseases (Simwambi et al., 2020). Therefore, considerable efforts to be enforced to minimize the consumption of the available clean water for large production of beer from the brewery industries due to water scarcity in African countries particularly Zambia, to meet the accepted worldwide beer production water efficiency and also reduce the discharge of a large amount of the partially treated or untreated effluent to receiving environment with a high concentration of pollutants. The paper reviews industrial and domestic wastewater production, identifies the major challenges of the wastewater treatment facilities, the quality of the effluent generated and major solution to the provision an improved effluent quality for reuse. 


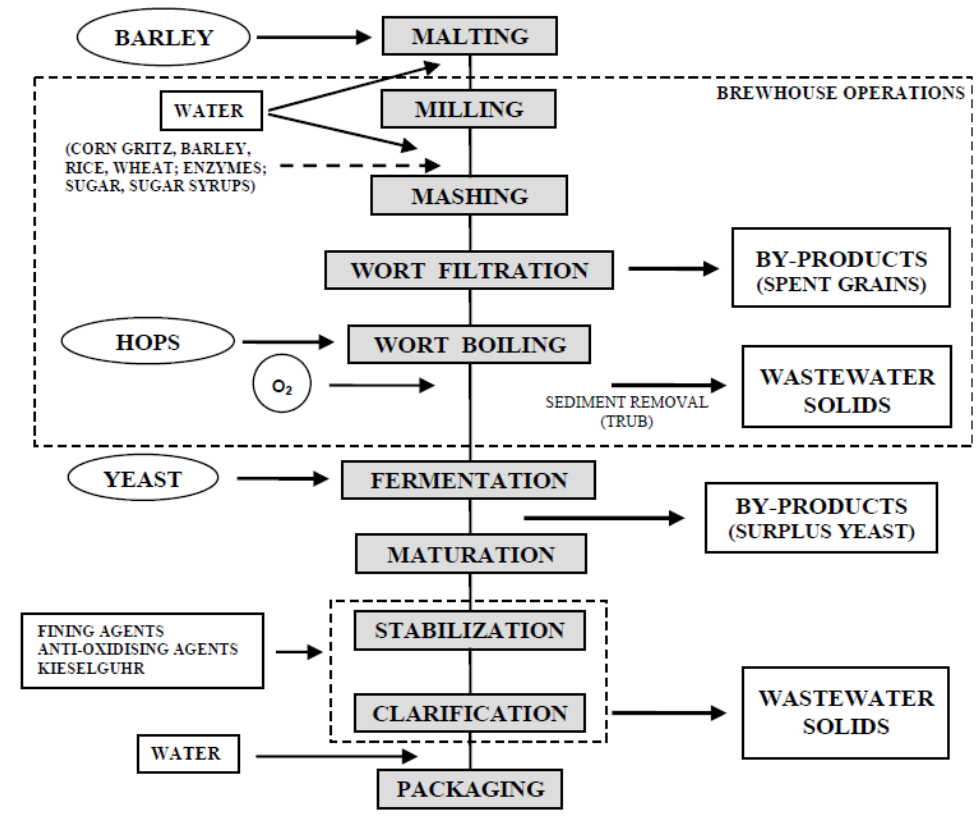

Figure 1 Technological process in conventional breweries (source (Jaiyeola and Bwapwa 2016))

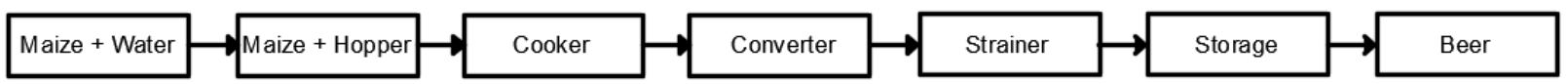

Figure 2 Technological process in Traditional Breweries (source (Chitsika et al., 1992)
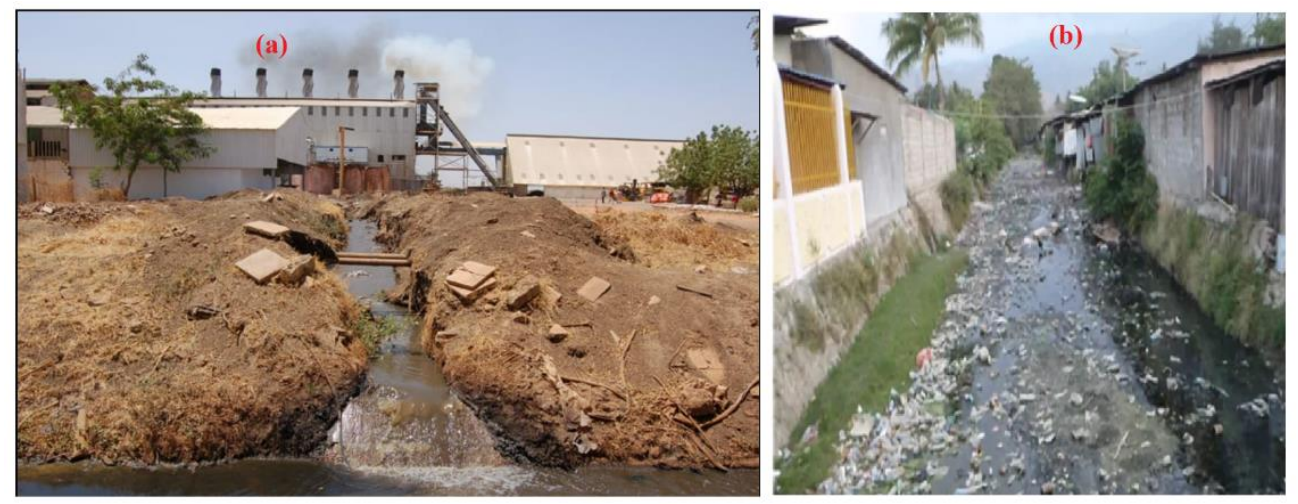

Figure 3 Brewery wastewater discharge (a) and municipal wastewater (b). (source: Industrial Waste Management National Water Supply and Sanitation Council (NWASCO) in Lusaka, Zambia)

\subsection{The concentration of untreated wastewater from breweries} and cities in Zambia

Industrial wastewaters from the breweries are a mixture of discharges from different plant sources: spent grains, kieselguhr, waste yeast, and sprinkled beer from packaging, as well as chemicals used in Clean in Place (CIP) units. (e.g. sodium bicarbonate, acetic acid, and nitric) are different types of these discharges (Enitan et al. 2015). The quality of brewery wastewater is mainly characterized by its physicochemical parameters which include the chemical oxygen demand, the biological oxygen demand, the total suspended solids, $\mathrm{pH}$, total Kjeldahl nitrogen, and total phosphates (Manyuchi et al., 2018). Moreover, the concentration of these pollutants at a high level is an indication of the health-threatening and negative impact on the different environments (Kanu et. al., 2011).

The brewery industries in Zambia were observed to generate wastewater of high concentrations of the $\mathrm{pH}, \mathrm{BOD}$, TSS COD, TDS (Zambian breweries in Lusaka), above the set allowable limits for discharge (Table 1). Also, observation was made for the wastewater concentrations at the municipal and domestic discharges to the treatment plants and sewer lines of high concentration in pollutants load. As a result, methods of characterizing wastewaters based on a few pollutants that indicate the average quality has been developed (Enitan et al. 2015). This has aided in the development of guidelines or standards to regulate the discharge of wastewater into sewer lines or water bodies (Sambo et al. 2019). 
The regulations are based on the Uniform Emission System (UES) or Environmental Quality Objectives (EQO), none of which is completely capable of dealing with some of the more complicated environmental management issues that occur in the water environment in Zambia.

Table 1 The raw wastewater of brewery industries and municipal in Lusaka, Zambia

\begin{tabular}{lllllllll}
\hline Parameter & Unit & $\begin{array}{l}\text { Zambian } \\
\text { Breweries } \\
\text { (Lusaka) }\end{array}$ & $\begin{array}{l}\text { National } \\
\text { Breweries } \\
\text { (Lusaka) }\end{array}$ & $\begin{array}{l}\text { National } \\
\text { Breweries } \\
\text { (Kafue) }\end{array}$ & $\begin{array}{l}\text { Influent } \\
\text { Trickling } \\
\text { Filters } \\
\text { (Average) }\end{array}$ & $\begin{array}{l}\text { to } \\
\text { Stabilizationt } \\
\text { Ponds } \\
\text { (Average) }\end{array}$ & $\begin{array}{l}\text { Maximum } \\
\text { Permissible } \\
\text { value } \\
\text { (Zambia) }\end{array}$ \\
\hline $\mathrm{pH}$ & & 10.2 & 4.8 & 7.6 & $6-8$ & $7.1-8.5$ & $6-9$ \\
$\mathrm{BOD}$ & $\mathrm{mg} / \mathrm{L}$ & 1200 & 256.7 & 320 & 345 & 207 & 50 \\
$\mathrm{COD}$ & $\mathrm{mg} / \mathrm{L}$ & 2720 & 845 & 503 & 532 & 165 & 120 \\
$\mathrm{TDS}$ & $\mathrm{mg} / \mathrm{L}$ & 4960 & 760 & 722 & - & - & 1200 \\
Sulphate & $\mathrm{mg} / \mathrm{L}$ & 60 & 2.5 & 26 & - & - & 500 \\
Chloride & $\mathrm{mg} / \mathrm{L}$ & 28 & 128 & 16 & - & - & 1000 \\
\hline
\end{tabular}

\subsection{Environmental impact of brewery industries and} municipal wastewater

Traditional brewery wastewater, which primarily uses water and maize as raw materials, can be warm and sterile, and degrade quickly when discharged into sewers or streams, raising BOD and contributing to sewage treatment plant organic overloading (Chimuriwo, 2016). However, the municipal wastewater treatment plants (WWTPs) find it extremely difficult to fulfill their consents due to additional suspended solids and $\mathrm{COD} / \mathrm{BOD}_{5}$ (Wamukwamba and Share 2001). The degradation of organic substances emits foul gases and cause greenhouse gases, eutrophication, and waterborne diseases (Arceivala and Asolekar 2006). The municipal wastewater also poses great risk to the environment due to high nutrients (nitrogen and phosphorus) and organic matter load to the environment leading to high number of cases for outbreak of waterborne diseases, eutrophication and loss of aquatic life.

\subsection{Wastewater Treatment in Lusaka, Zambia.}

Generally, treatment of wastewater is an essential aspect that is considered worldwide for the control of environmental pollution particularly drinking water sources, aquatic life, an outbreak of waterborne diseases such as cholera, typhoid, and others (Qadri and Faiq 2020). The wastewater treatment in most of the African countries uses outdated systems which due to high maintenance and operation cost, and they discharge effluents with high pollutants concentrations load to the environment. Additionally, the wastewater generated from the industries and domestic highly contaminated particularly with high metal concentration in the Zambia, is mostly used at raw for irrigation of crops according to (Kapungwe 2012, Kapungwe 2014). Most of the Zambian residents are observed to manage the wastewater particularly from the household sector by use of septic tanks and pit latrines which are observed to be poorly maintained and operated, due to overfilling and inadequate desludging processes resulting to groundwater pollution and degradation of the environment. However, for brewery wastewater, despite large production of it from the industries, treatment is a major challenge observed in particularly the Zambian breweries. Relatively, generally used management ways of the brewery waste and wastewater at the first stage are physical treatment methods such as screening and sedimentation (Table 2).

According to (Simwambi et al. 2020), wastewater in Zambia is treated by use of the aerated stabilization ponds acting as the conventional treatment methods which are currently not in good condition due to high operation and maintenance cost. The poorly operated treatment systems in Zambia led to outbreak of waterborne diseases such as typhoid and cholera and of about hundreds of deaths and thousands of infections are yearly recorded. Moreover, the majority of industries mostly beer brewing industries depend on public sewers to discard off their wastewater (Chibwe, 2012). The sewer channel facilities are situated in industrial areas with proper sewage connections to the municipal sewer system (Sambo et al. 2019). Previous studies observed that the applicable law for wastewater quality level for discharge was not in effect at the time the industries were established, however, most industries without treatment facilities discharged the untreated wastewater to the sewer lines (Ronald, 2011), which led to degradation of the ecosystem. Screening is used to remove large objects, such as branches, plastic, paper, and cloth. This is done to avoid blockage of the pipelines and the waste from the screens is ranked manually and dewatered then the local council collects it at a fee.

Table 2 Brewery industries in Zambia, treatment and disposal methods for wastewater

\begin{tabular}{llll}
\hline City/Town & Name of Breweries & Method of Treatment & Effluent Disposal \\
\hline Lusaka & Zambian Breweries & None & Public Sewers \\
Lusaka & National Breweries & Screening & Public Sewers \\
Kitwe & Northern Breweries & Sedimentation & Public Sewers \\
Kafue & National Breweries & Screening & Public Sewers \\
\hline
\end{tabular}




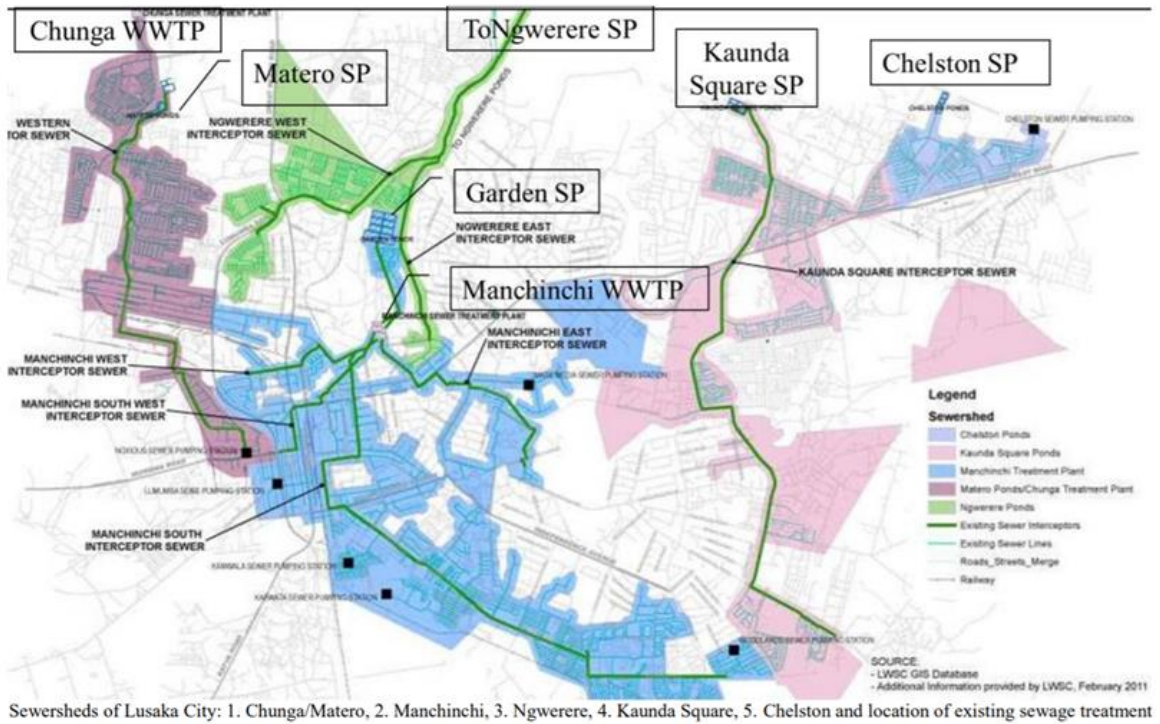

Figure 4 Wastewater Treatment Plants in Lusaka, Zambia. Source: (Maina et al. 2020)

The treatment plants and drainage sewer systems are operated and maintained by the Lusaka water and sewerage company (LWSC). Moreover, in Lusaka, Zambia there are 2 conventional WWTPs (Chunga and Manchinchi) consisting of trickling filters and stabilization ponds working together and 4 waste stabilization ponds (WSPs) (Matero, K/Square, Ngwerere, and Chelstone) as stated by (Wamukwamba and Share 2001). The conventional treatment plants comprise screening \& grit removal facilities, primary sedimentation tanks (PST), biological filters, final sedimentation tanks (FST), sludge treatment facilities, and stabilization ponds. All these facilities are used for the treatment of industrial and domestic wastewater together. Most importantly, the industrial wastewater goes to the public sewers and is treated by the convectional wastewater treatment plants (Ronald, 2011). The commonly applied conventional treatment processes (Figure 6) are preliminary treatment stage comprises screening, sand and grit removal and comminution, that aids in the removal of large floating objects (rags, maize cobs, pieces of wood, etc.) and heavy inorganic particles (Phiri et al., 2014) and primary stage involved in the further removal of solids from the liquid phase and a high degree of clarification reduced biological treatment process load (Kennedy-Walker, 2015) and with the estimated removal of about $50-70 \%$ TSS, $25-50 \%$ BOD and $65 \%$ of oil and grease (Kloc and González 2012). Moreover, biological treatment stage the microorganisms break down organic waste in the water and three main approaches that is fixed film, suspended film and lagoon systems are applied (Massoud et al., 2009). Furthermore, secondary sedimentation stage, the removal of sludge takes place where the oil and grease are removed by skimming and the solids by sedimentation finally the sludge treatment stage collection and treatment of the sludge produced from the conventional wastewater treatment takes place.

The effluent from the trickling filters is usually directed to a stabilization pond for further treatment to a better end quality effluent. However, the treatment process leads to the production of a large volume of sludge and with the sludge drying beds sited at the Manchinchi and Chunga WWTPs, hence, the dried sludge is sold for agricultural use. Additionally, the sludge contains a great amount of organic matter that is biodegradable (Phiri et al. 2014). The treatment facilities serving Lusaka are observed to be hydraulically overloaded with around twice the maximum design flow (Wamukwamba et al. 2001). The stabilization pond scheme is easy to operate, and regular solid waste removal at the screen is the most important maintenance task of which in most cases it appears to be overloaded with the solids due to inadequate monitoring. However, it is necessary to remove accumulated sludge at the base of the ponds; at the interval of about 5 to 10 years (Wamukwamba et al. 2001).

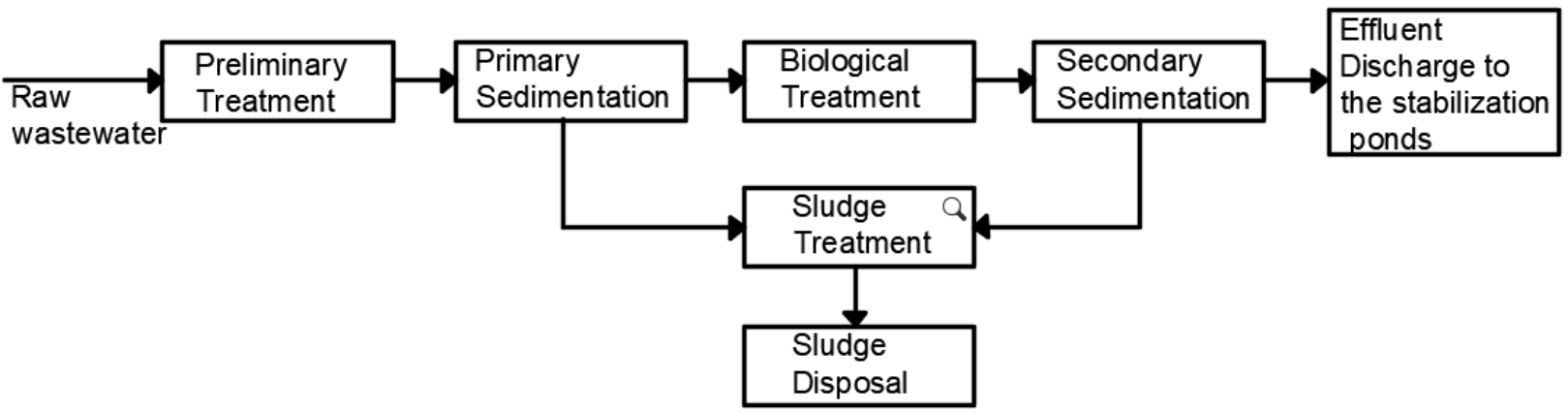

Figure 5 Conventional Wastewater Treatment processes in Zambia 
1.4 Effluent quality of the wastewater treatment plants and WSPs in Lusaka, Zambia

Table 3 The effluent quality range of the WWTPs and WSPs in Lusaka

\begin{tabular}{|c|c|c|c|c|}
\hline Treatment system & $\begin{array}{l}\begin{array}{l}\text { ZEMA } \\
\text { standard }\end{array} \\
\end{array}$ & Discharge & $\begin{array}{l}\text { Tricking filters and WSPs } \\
\text { (range) }\end{array}$ & $\begin{array}{l}\text { Waste stabilization } \\
\text { ponds (range) }\end{array}$ \\
\hline $\mathrm{pH}$ & $6-9$ & & $7.1-7.9$ & $6.4-9$ \\
\hline Settleability $\mathrm{m} / \mathrm{L}$ & 0.5 & & $0-0.5$ & $0-0.2$ \\
\hline $\mathrm{TSS}, \mathrm{mg} / \mathrm{L}$ & 100 & & Not done & Not done \\
\hline Turbidity NTU & 15 & & $34.5-82.3$ & $26.9-211$ \\
\hline BOD $(\mathrm{mg} / \mathrm{L})$ & 50 & & $30-266$ & $18-55$ \\
\hline $\mathrm{COD}(\mathrm{mg} / \mathrm{L})$ & 90 & & $178-1455$ & $55-238$ \\
\hline
\end{tabular}

The conventional wastewater treatment plants Manchinchi and Chunga were observed to be ineffective in the removal of turbidity (34.5 NTU and 82.3 NTU) respectively, BOD 266mg/l at the effluent of Chunga treatment plant and COD $(178 \mathrm{mg} / \mathrm{l}$ and $1455 \mathrm{mg} / \mathrm{l})$ at Manchinchi and Chunga treatment plants respectively, to the required standards as stipulated by the ZEMA (Table 3). The inefficiency of the treatment plants was due to bad condition due to overloading and hence, large capital investment is needed to bring them to a better function at their design capacity and efficiency. The wastewater treatment facilities such as the WSPs have been in use for more than 30 years, and their effective volume has decreased, hence the treatment capacity. Despite the sludge accumulation in the ponds, the effluent $\mathrm{BOD}_{5} 18 \mathrm{mg} / \mathrm{l}$, $48 \mathrm{mg} / \mathrm{l}$ and $8.9 \mathrm{mg} / \mathrm{l}$ of $\mathrm{Ngwerere}, \mathrm{K} /$ square and Chelstone WSP respectively were within the allowable limits by ZEMA $50 \mathrm{mg} / \mathrm{L}$ (Simate et al. 2011) except for Matero WSP achieved an effluent quality 55mg/l slightly above the allowable limit (Table 3). The turbidity effluent load (56.2 NTU, 211NTU, 51NTU and 26.9NTU, for Matero, Ngwerere, K/square and Chelstone WSP respectively were above the allowable limits (Table 3) while the COD effluent of the WSP Ngwerere (95mg/l), K/square (184mg/l) and Matero $(238 \mathrm{mg} / \mathrm{l})$ were observed to be above the set limits except for the COD effluent load of Chelstone $(55 \mathrm{mg} / \mathrm{l})$ was within the allowable limits (Sambo et al. 2019).

The stabilization ponds have not been cleaned or desludged since construction, resulting in the accumulation of excess sludge, which has consequently reduced their volumetric capacity and efficiency of operation. The tricking filters particularly at Chunga treatment systems were observed to be inefficient in the removal of most of the pollutants in the wastewater, this was attributed to the poor maintenance observed in the damaged mechanical parts. Furthermore, power failures are also commonly observed during the treatment period resulting in also the ineffective performance of the system (Wamukwamba and Share 2001). Therefore, the LWSC developed a "Quality Policy Statement" to control effluent wastewater quality into sewers. Based on the Statement, the industries are demanded to ensure pretreatment of the wastewater prior to discharge thus controlling highly contaminated wastewater into sewers and to the environment. However, the request has not been followed satisfactorily hence, high polluted wastewater inflow comprising of toxic substances causes biological reaction failure, and the quality of the treated wastewater is poor, with $\mathrm{BOD}_{5}$ levels exceeding $250 \mathrm{mg} / \mathrm{L}$ (Table 4) (Sambo et al. 2019).

Table 4 Current situation of the Treatment Plants in Lusaka

\begin{tabular}{|c|c|c|c|c|}
\hline Treatment Facility & $\begin{array}{l}\text { Started } \\
\text { operation }\end{array}$ & Design capacity & Treatment process & Current condition \\
\hline $\begin{array}{l}\text { Manchichi } \\
\text { Works }\end{array}$ & 1969 & $36,000 \mathrm{~m}^{3} /$ day & $\begin{array}{l}\text { Biological filter (Trickling filter) } \\
\text { (Convectional) }\end{array}$ & $\begin{array}{l}\text { Quantity } \\
\text { received: } 65,000 \\
\mathrm{~m}^{3} / \text { day }\end{array}$ \\
\hline Chunga Sewage Works & 1973 & $9,100 \mathrm{~m}^{3} /$ day & $\begin{array}{l}\text { Biological filter (Trickling filter) } \\
\text { (Convectional) }\end{array}$ & $\begin{array}{l}\text { Quantity } \\
\text { received: } 16,000 \\
\mathrm{~m}^{3} / \text { day }\end{array}$ \\
\hline Kaunda Square SP & - & $3,600 \mathrm{~m}^{3} /$ day & (Non-Convectional) & - \\
\hline Matero SP & - & $7,100 \mathrm{~m}^{3} /$ day & (Non-Convectional) & - \\
\hline Ngwerere SP & - & $8,350 \mathrm{~m}^{3} /$ day & (Non-Convectional) & - \\
\hline Chelston SP & - & $2,700 \mathrm{~m}^{3} /$ day & (Non-Convectional) & - \\
\hline Garden MP & - & $36,000 \mathrm{~m}^{3} /$ day & (Non-Convectional) & - \\
\hline
\end{tabular}

\subsection{Policy Aspects}

The Water Resource Management, Act No. 21 of 2011 specifies that wastewater disposal standards should be within the broad 
objective for environmental protection. It also indicates that since the poor rely often on the environment for their livelihood, attacking poverty in urban, pre-urban, and rural areas is necessarily by improving people's ability to derive a livelihood from natural resources. In addition, the Zambia Health Policy directs that to have healthy nation wastewater discharged to the environment should strictly adhere to the standards, this will reduce the risk of infections to humans, death of aquatic life, and environmental degradation (Sambo et al. 2019).

\section{CONCLUSION}

The brewing industries discharge large volume of polluted water to the environment with or without treatment at high concentration of contaminants. The treatment plants are observed to be inefficient in the removal of pollutants due to overloaded and overfilling that is attributed to high operation and maintenance cost. The wastewater with high concentration of COD, BOD, TSS, TDS was recorded in the study which requires effective treatment facilities.

\section{RECOMMENDATION}

The disadvantages of conventional wastewater treatment encourage researchers to develop a new, cost-effective method for treating high-organic load wastewater. High maintenance costs due to greater energy requirements, as well as the generation of massive sludge deposition and finally operational complexities, are all major challenges in adopting these techniques. Therefore, an onsite wastewater treatment particularly for the brewery industries is recommended to reduce overloading of the WWTPs. The nature of anaerobic treatment facilities for the wastewater such as an upflow anaerobic sludge blanket (UASB), expanded granular sludge bed (EGSB) system anaerobic packed bed reactors (APBR), and fluidized bed reactor (FBR) are very effective in the removal of high organic matter (BOD and COD), total suspended solids and turbidity.

\section{ACKNOWLEDGMENT}

Thanks to our mentor, Prof. Chen Hongbin and our research group for all kinds of support. We also thank Mercy Mumba for her comments and suggestions. All authors have read and agreed on the manuscript version to be published.

\section{REFERENCES}

[1] Arceivala, S. J., \& Asolekar, S. R. (2006). Wastewater treatment for pollution control and reuse, Tata McGraw-Hill Education.

[2] Chibwe, M. (2012). Management and Disposal of Municipal Wastewater in Lusaka city, Zambia, University of Zambia.

[3] Chimuriwo, B. (2016). An assessment of water quality along Mukuvisi River, Harare, Zimbabwe.

[4] Cooley, H., Ajami, N., Ha, M. L., Srinivasan, V., Morrison, J., Donnelly, K., \& Christian-Smith, J. (2014). Global Water Governance in the Twenty First Century. The World's Water: The Biennial Report on Freshwater Resources. P. H. Gleick. Washington, DC, Island Press/Center for Resource Economics: $1-18$
[5] National Research Council. (2012). Water reuse: potential for expanding the nation's water supply through reuse of municipal wastewater, National Academies Press.

[6] Enitan, A. M., Adeyemo, J., Kumari, S. K., Swalaha, F. M., \& Bux, F. (2015) "Characterization of brewery wastewater composition."

[7] Fillaudeau, L., Blanpain-Avet, P., \& Daufin, G. (2006). "Water, wastewater and waste management in brewing industries." Journal of cleaner production 14(5): 463-471.

[8] Grogan, D. S., Wisser, D., Prusevich, A., Lammers, R. B., \& Frolking, S (2017). "The use and re-use of unsustainable groundwater for irrigation: a global budget." Environmental Research Letters 12(3): 034017.

[9] Haworth, A., \& Simpson, R. (Eds.). (2004). "Local alcohol issues in Zambia." Moonshine Markets: Issues in Unrecorded Alcohol Beverage Production and Consumption 39.

[10] Jaiyeola, A. T., \& Bwapwa, J. K. (2016). "Treatment technology for brewery wastewater in a water-scarce country: a review." South African journal of science 112(3-4): 1-8

[11] Kanu, I., \& Achi, O. K. (2011). "Industrial effluents and their impact on water quality of receiving rivers in Nigeria." Journal of applied technology in environmental sanitation 1(1): 75-86.

[12] Kapungwe, E. M. (2012). "Traditional farming practices and wastewater irrigation farming in peri-urban Zambia." Indonesian Journal of Geography 44(2): 104-120.

[13] Kapungwe, E. M. (2014). "Multiple Livelihoods and Wastewater Irrigation Farming in Peri Urban Areas in Zambia: Opportunities and Challenge." 14(2).

[14] Kebede, T. B. (2018). "Waste water treatment in brewery industry, Review." International Journal of Engineering Development and Research 6(1), 23219939.

[15] Kennedy-Walker, R. (2015). Planning for Faecal Sludge Management in informal urban settlements of low-income countries: A study of Lusaka, Republic of Zambia, Newcastle University.

[16] Kloc, J., \& González, I. M. (2012). "The study of biological wastewater treatment through biofilm development on synthetic material vs. membranes." Worcester Polytechnic Institute.

[17] Maina, G. I., Mwakumanya, M. A., Wamukota, A. W., \& Kilifi, K. (2020). "Current Status in Quality of Treated Wastewater for Potential Reuse Scheme in Ruai, Nairobi County, Kenya."

[18] Manyuchi, M. M., Mbohwa, C., \& Muzenda, E. (2018). Bio treatment of Brewery Wastewater Treatment using Hycura. Proceedings of the International Conference on Industrial Engineering and Operations Management.

[19] Massoud, M. A., Tarhini, A., \& Nasr, J. A. (2009). "Decentralized approaches to wastewater treatment and management: applicability in developing countries." Journal of environmental management 90(1): 652659

[20] Nyuur, R. B., \& Sobiesuo, P. (2016). The history and development of brewing and the beer industry in Africa. Brewing, Beer and Pubs, Springer: 145-161.

[21] Phiri, J. S., Katebe, R. C., Mzyece, C. C., Shaba, P., \& Halwindi, H. (2014). "Characterization of biosolids and evaluating the effectiveness of plasticcovered sun drying beds as a biosolids stabilization method in Lusaka, Zambia." International Journal of Recycling of Organic Waste in Agriculture 3(3): 1 .

[22] Qadri, R., \& Faiq, M. A. (2020). Freshwater pollution: effects on aquatic life and human health. Fresh Water Pollution Dynamics and Remediation, Springer: $15-26$

[23] Rijsberman, F. R. (2006). "Water scarcity: fact or fiction?" Agricultural water management 80(1-3): 5-22.

[24] Mangule, M. R. (2011). Industrial waste management in Zambia: Case study of a Lusaka slaughterhouse.

[25] Sambo, P. T. (2019). The Environmental Management Act (2011): a basis for the growth of an environmental ethos and good environmental governance in Zambia? Law| Environment| Africa, Nomos Verlagsgesellschaft mbH \& Co KG.

[26] Fakayode, S. O. (2005). "Impact assessment of industrial effluent on water quality of the receiving Alaro River in Ibadan, Nigeria." African Journal of Environmental Assessment and Management 10: 1-13. 
[27] Simate, G. S., Cluett, J., Iyuke, S. E., Musapatika, E. T., Ndlovu, S., Walubita, L. F., \& Alvarez, A. E. (2011). "The treatment of brewery wastewater for reuse: State of the art." Desalination 273(2-3): 235-247.

[28] Simwambi, A., Yamba, F., Hibler, S., \& Mulenga, K. (2020). "Renewable Energy Potential of Sewage in Zambia." Open Journal of Applied Sciences 10(6): 328-350.

[29] Kpenou, S. (2018). Fresh water as Common Heritage and a Common Concern of Mankind. Research Handbook on Freshwater Law and International Relations, Edward Elgar Publishing.

[30] Sutton, J., \& Langmead, G. (2013). An enterprise map of Zambia, International Growth Centre in association with the London Publishing ....

[31] UNEP (2017). "UNEP 2007 Water utilisation in african beverage industries."

[32] Wamukwamba, C. K., \& Share, W. (2001). "Sewage waste management in the city of Lusaka."

\section{AUTHORS}

First Author - Zulu Bernard, BSC Bachelor of Education Science, currently pursuing a Master of Environmental Science and Engineering at Tongji University in Shanghai China. UNEPTONGJI Institute of Environmental Sciences and Sustainable Development (IESD) Tongji University, College of Environmental Science and Engineering, Tongji University, Shanghai 200092, China. Email: manbentry@yahoo.com
Second Author -Flory Kilingo Mkangombe, BSC Bachelor of Education Science, currently pursuing a Master of Environmental Science and Engineering at Tongji University in Shanghai China. UNEP-TONGJI Institute of Environmental Sciences and Sustainable Development (IESD) Tongji University, College of Environmental Science and Engineering, Tongji University, Shanghai 200092, China. Email: florymkangombe@ gmail.com

Third Author - Prof. Chen Hongbin, Biological wastewater treatment, industrial (petrochemical) wastewater recycling technology and application; State Key Laboratory of Pollution control and Resource Reuse, College of Environment Science and Engineering, Tongji University No 588 Miyun Rd. Shanghai, P.R. China,200092. Tel: 0086-21-65984569, Email: bhctxc@tongji.edu.cn

Correspondence Author - Prof. Chen Hongbin, , Email: bhctxc@ tongji.edu.cn, contact number Tel: 0086-21-65984569 